\title{
DISCUSSION
}

\section{APPLICATION OF ETYMOLOGY-VISUALIZATION TECHNIQUES TO TEACHING FINANCIAL ENGLISH VOCABULARY: A KOREAN EXPERIENCE}

\author{
Chung-Sim Ri, Chol-Su Kang \\ Kim Il Sung University, Democratic People's Republic of Korea
}

Received 29 April 2018

Revised 24 May 2019; Accepted 22 July 2019

\begin{abstract}
It is a common belief that English for Specific Purposes students (herein ESP students) in general, and Financial English students (herein FE students) find it harder than Basic/General English (GE) for a number of reasons, one of which is differences between FE and GE. The paper first identifies the most important factors in teaching FE by clarifying such differences between FE and GE and pointing out peculiarities of FE vocabulary. Then, we share our experience in seeking effective FE vocabulary teaching techniques to overcome our Korean students' difficulties in the ESP course compared with their GE course. In our efforts, we piloted different techniques which combine etymology and visualization for teaching FE vocabulary, including derivative reasoning technique, monolingual reasoning technique, multilingual reasoning technique, semantic contrast technique, word decomposition technique, and definition grouping technique. We also checked our students' retention of some FE vocabulary items taught through both traditional and piloted techniques, and initial results manifest that these etymology-visualization techniques promise to be effective. Above all, the paper presents a glimpse of ESP teaching/learning in our country in the hope that what works in our case in Korea can also be effectively applied elsewhere.
\end{abstract}

Keywords: etymology, visualization, ESP vocabulary, Financial English

\section{Introduction}

After the Basic English course, all the students in our University (Kim Il Sung University, Democratic People's Republic of Korea (DPRK)) take an ESP course according to their majors. Students of Finance College go through the Financial English course. The students feel FE course harder than Basic English course although they are both English. FE terms are hard for them to acquire because they are specific to financial situations, not general situations. They tend to acquire FE terms mechanically using word-for-word translation technique, i.e. L1 word for L2 word, or vice versa, as shown in bilingual English-Korean dictionaries. They feel embarrassed when they come across new terms not shown in bilingual dictionaries. In some cases, they merely transfer the words they knew from the Basic English course to the new context, which may not be suitable. For example, 'debtors' in balance sheets means 'the amounts of money that are owed to a company, which are recorded as assets on its balance sheet' in Oxford Business English Dictionary for Learners of English 2005 (OBEDLE, 2005), not the plural form of 'a person who owes money'. They do not consult specific dictionaries of financial terms because they think such words are not new, and they already know their meanings. They are unaware of other meanings, especially contextual meanings, of those words, and 
continue to use them mechanically. These challenges require a study on efficient ways of acquiring ESP - FE vocabulary.

Since most of the students believe the Basic English course is easier than the ESP course (Financial English course), it is highly necessary to find effective ways to make the ESP course as natural and easy as the Basic English course, one of which is the use of different etymology-visualization techniques. Our pilot application of these techniques demonstrates that they are useful in FE vocabulary acquisition and retention. In other words, students' FE vocabulary learning is facilitated when teachers employ a wide variation of etymology-visualization techniques. Our efforts are based on the following theoretical consideration.

\section{Literature Review}

\subsection{Relationship between ESP and GE}

As for the meaning of the term " 2 nd language for specific purposes" (Bloor \& Bloor, 1986; Flowerdew \& Peacock, 2001a) which Alan and Catherine summarized in their book (2004), there exist two views: one believes that a specific-purpose language is a restricted repertoire of a general language system and the second language learner first needs to learn the basic core of the second language before he/she can learn additional elements, such as items that feature strongly in the target situations of interest while the other (Bloor \& Bloor, 1986) posits that languages for specific purposes are varieties of language and that there is no such thing as a generalpurpose language, and the learner can acquire the common elements from studying any variety of a language while at the same time learning the specific forms and conventions appropriate to that variety.
There are issues that need discussing in the views above. There exist no tools for no purpose. Language, a tool for communication, was born with its own purpose. The question is to define the scope of the purpose, which should be considered with the development of language. Language is used between people in a society. So language development accompanies social development. The more the society develops, the more labor is divided and diversified and the more knowledge is specialized, which inevitably leads to the specialization of language - "the garment of thought", as Ferdinand de Saussure (1959) puts it. This should define the extent of language purposes in accordance with that of language development accompanied by social development: general purposes and specific purposes.

Language for general purposes can be taken as the root from which language for specific purposes is branched. The former has a word bank of high frequency in general situations while the latter has a word bank of higher frequency in specific situations rather than others.

Language for general purposes and language for specific purposes are defined according to situations. As yesterday's knowledge becomes today's common sense with the growing level of people's culture and education, today's language for specific purposes can be tomorrow's language for general purposes. And specialized branches of science are combined to produce another new specialized branch, which shows that yesterday's language for general purposes can be today's language for specific purposes with a derivative meaning. It may be of limited duration.

It would be regarded as desirable to educate the root language prior to branches. The root language education (General English herein) and branch language education (Financial 
English herein) are intimately related as the latter is rooted from the former. With ESP and GE being so interrelated, ESP can be defined in the following formula: 'ESP = Major Knowledge + English Knowledge'. English knowledge is framed through a Basic English course. Major knowledge consists of specific concepts or definitions and their combination which are regarded as vocabulary and/or specific systems of terminology.

Vocabularies are like raw materials for producing or building a language. Learners can produce a new product, i.e. ESP, by inputting new raw materials (vocabulary) and making a slight change to the basic production process (grammar) already established through the Basic English course. It is reasonable to make useful techniquees for learning or teaching vocabulary frequently used in specific domains, provided that the difference between GE naturally acquired in the infant stage and ESP intentionally acquired in the professional stage mainly lies in vocabulary. To get knowledge is to get terms for the knowledge. From this point of view, we believe that the most important point that distinguishes Financial English (FE) from GE exists inside vocabulary rather than grammar, context or stylistics.

Financial English = Financial Knowledge + English Knowledge

Reviewing the trends in the area of vocabulary teaching through various techniques used by ESL/EFL teachers (Monarch, 2015; Wilkins, 1972; Carter \& McCarthy, 1988; Nation, 1990; Arnaud \& Bejoint, 1992; Coady \& Huckin, 1997; Schmitt, 1997, 2000; Mofareh, 2015; Shigao, 2012; Nina, 2014), we find that ESP teachers need to notice the points peculiar to their ESP vocabulary and find suitable teaching techniques to their own learners. Below are several peculiarities of $\mathrm{FE}$ in our view.

\subsection{Characteristics of Financial English vocabulary}

Like other sets of terminology, a large amount of Financial English (FE) vocabulary is derived from General English (GE) vocabulary. For instance, in Longman Dictionary of Contemporary English (2009), 'portfolio' has four meanings: (1) a large flat case used especially for carrying pictures, documents, etc.; (2) a set of pictures or other pieces of work that an artist, photographer, etc. has made; (3) a group of stocks owned by a particular person or company (4) (British English) the work that a particular government official is responsible for. 'Portfolio' has its Italian word origin portfolio, from portare 'to carry' + foglio 'leaf, sheet'. The first meaning is derived from its Italian origin while the second, the third, and the fourth are derived from the first general meaning of 'portfolio'. The fact that the FE vocabulary 'portfolio' has its financial meaning in the third place out of the four meanings can lead us to assume that many, if not all, other FE vocabulary items, could also come from GE vocabulary. This assumption will be clarified later in the paper.

However, FE vocabulary is unique (Kisin, 2014). It is necessary to point out features peculiar to FE vocabulary which might be challenges for teaching or learning it. First, a number offinancial phenomena or concepts can be expressed in different English vocabulary in British or American English. For instance, in OBEDLE (2005), 'debtors' is described as 'the amounts of money that are owed to a company, which are recorded as assets on its balance sheet' while 'accounts receivable' as 'the amounts of money that are owed to a business by its customers, shown as an asset on its balance sheet.' This shows that the two words 'debtors' and 'accounts receivable' are identical in their meaning although they are 
disparate in their appearance. Not only do British and American English (BE and AE) differ, but even in one of those varieties, there exists different vocabulary entries for identical financial phenomena or concepts. The same financial phenomena/concepts can be referred to in different ways, just like synonyms in GE. This causes another difficulty for acquiring FE vocabulary, so there must be some consistent way to unite all these synonyms, and maybe only one of them is chosen to be the term for the phenomenon/concept while others have to sacrifice. In other words, we have to try to ensure one-to-one correspondence: one concept is expressed only by one term.

As discussed above, FE vocabulary is rooted in GE vocabulary, so it is necessary to contrast original words and derivatives. Nevertheless, FE vocabulary may not always find their Korean equivalents, which indicates that learners need to acquire the ways to understand and guess the meaning of FE vocabulary, and tracing word origins is one of such ways. Etymology hence comes in handy to facilitate FE vocabulary acquisition. Below is relevant literature on etymological visualization.

\subsection{Helping students acquire FE vocabulary by visualizing its etymology}

Memorization can be enhanced when associated, relevant information is provided, or known knowledge is activated. "Discovering the common roots of words, language learners soon understand the meaning of many unknown words they have never seen before, derived from the same root. Etymology is useful, effective and interesting in language learning. Etymology which is one of the most systematic, enjoyable and effective ways of enhancing word power will increase the learners' ability to figure out unknown and difficult words with ease and without continual reference to unabridged sources." (Masoud and Masoud, 2011).

Etymological or historical tracing is effective in such a case that the present meaning is not directly related to its inherent meaning. Both literal meanings and metaphorical meanings are products of culture and history (Shigao, 2012). From learning the etymology (or historical development) of a word, learners can improve their metaphorical cognitive abilities and learning the etymology of a word will certainly promote their comprehension of new words.

Let us consider some examples. 'Pound' (today's British monetary unit) is derived from weight unit 'pound' since the ancient British used rice as general equivalent. 'Blue chip' (today's big and secure company stocks) is derived from gambling whose blue chip is of highest points. 'Payroll' means 'a list of people employed by a company showing the amount of money to be paid to each of them'. Here the word 'roll' of 'payroll' does not match with 'list'. Tracing the history of bookbinding, a paper was kept in the form of a roll. Then learners can find it easy to match 'roll' with 'list'. As can be seen, etymology proves useful here in learning FE vocabulary.

Another help to FE vocabulary learning is visualization. In fact, visualization has been applied to science education, especially natural science such as chemistry, physics, biology, etc. Karen et al. (2011) analyzed 65 research articles on the application of visualization in a number of science subjects, most of which were in chemistry and general science. They concluded, "There is general agreement in the educational community that visualization is an effective teaching tool. Current applications of visualization are found in many teaching contexts, including mathematics, reading, science and technology." (Karen et al. 2011). 
Gilbert (2005) also states that processes of visualization are widely used throughout science and science education. In language learning and teaching in particular, Wilkins (1972) claims that, according to the psychology of language, people learn and better retain words which have been presented to them with a range of visual and other associations. Seeing is believing.

What about visualization of FE vocabulary? Is is taken for granted that the tangible or concrete is acquired more naturally than the intangible or the abstract. For FE the issue in question, FE vocabulary is quite abstract or intangible while GE is concrete or tangible. The more abstract the vocabulary is, the more difficult it is to be visualized, while the more concrete the vocabulary is, the easier it is to be visualized. In addition, the more abstract the FE vocabulary is, the more necessary it is to be visualized for learners to easily acquire it. Finance, one among social sciences, is distinct from natural sciences, so it is hard to visualize abstract FE vocabulary except for such a few concrete words as 'money' or 'coin'.

Speakers' lexicon develops from the simple to the complex and from the concrete to the abstract, reflecting the past, present and future materials and phenomena in the world. When the abstract meaning of FE vocabulary comes from the meaning of the concrete origin, it is possible to visualize that vocabulary through etymological restoration. Mayer and Anderson (1991) found that the combination of visualization (animation in this case) and verbal or textual information enhanced understanding of scientific explanations and concepts. Etymology together with visualization can magnify learners' comprehension, acquisition, retention and recall for the target vocabulary. In a word, etymology-based visualization techniques could convert abstraction into concretion to facilitate vocabulary acquisition. Visualization thus can help learners guess, understand and memorize FE vocabulary in a much easier way.

\section{abstraction $\longrightarrow$ etymology + visualization $\rightarrow$ concretion}

Figure 1. Abstraction-concretion process

With these in mind as a foundation, we set out to conduct our experiment.

\section{The Experiment}

\subsection{Financial English vocabulary analysis}

In order to find out the relationship between GE and FE vocabulary, we analyzed the vocabulary in a bilingual dictionary 'Samhung English-Korean Dictionary'. The dictionary has about 300,000 entries, 3009 out of which are about finance and economics. 2062 of 3009 are lexical items with only one meaning. A few items (38) of 2062 consist of a single word such as 'consol', 'arbitrage' and 'higgle', etc. which are impossible to be divided into smaller units, while the rest of 2062 are phrases like 'acceptance bank', 'account payable', 'prompt note', 'accountant', 'unrepaid', etc. Analyzing their meanings, we identify the following 
Table 1. Proportion of FE vocabulary derived from GE

\begin{tabular}{|c|c|c|c|c|}
\hline $\begin{array}{l}\text { Total } \\
\text { meanings of } \\
\text { an entry } \\
\text { (A) }\end{array}$ & $\begin{array}{c}\text { Total entries } \\
\text { (B) }\end{array}$ & $\begin{array}{l}\text { Total entries with } \\
\text { financial meaning } \\
\text { being the primary } \\
\text { sense } \\
\text { (C) }\end{array}$ & $\begin{array}{l}\text { Total entries with } \\
\text { financial meaning } \\
\text { not being the } \\
\text { primary sense } \\
\text { (D) }\end{array}$ & $\begin{array}{l}\text { Proportion of entries } \\
\text { whose financial } \\
\text { meaning can be } \\
\text { matched with GE } \\
\text { (D/B) }\end{array}$ \\
\hline 2 & 406 & 274 & 132 & 32.5 \\
\hline 3 & 163 & 62 & 101 & 62.0 \\
\hline 4 & 114 & 44 & 70 & 61.4 \\
\hline 5 & 76 & 10 & 66 & 86.8 \\
\hline 6 & 47 & 5 & 42 & 89.4 \\
\hline 7 & 39 & 5 & 34 & 87.2 \\
\hline 8 & 26 & 7 & 19 & 73.1 \\
\hline 9 & 13 & 3 & 10 & 76.9 \\
\hline 10 & 12 & 3 & 9 & 75.0 \\
\hline 11 & 9 & 0 & 9 & 100.0 \\
\hline 12 & 8 & 1 & 7 & 87.5 \\
\hline 13 & 1 & 0 & 1 & 100.0 \\
\hline 14 & 6 & 0 & 6 & 100.0 \\
\hline 15 & 8 & 0 & 8 & 100.0 \\
\hline 16 & 2 & 0 & 2 & 100.0 \\
\hline 17 & 4 & 0 & 4 & 100.0 \\
\hline 18 & 1 & 0 & 1 & 100.0 \\
\hline 19 & 1 & 0 & 1 & 100.0 \\
\hline 22 & 1 & 0 & 1 & 100.0 \\
\hline 23 & 2 & 0 & 2 & 100.0 \\
\hline 24 & 2 & 0 & 2 & 100.0 \\
\hline 25 & 1 & 0 & 1 & 100.0 \\
\hline 27 & 2 & 0 & 2 & 100.0 \\
\hline 28 & 1 & 0 & 1 & 100.0 \\
\hline 31 & 1 & 0 & 1 & 100.0 \\
\hline 36 & 1 & 0 & 1 & 100.0 \\
\hline $2-36$ & 947 & 414 & 533 & 56.3 \\
\hline $3-36$ & 541 & 140 & 401 & 74.1 \\
\hline
\end{tabular}

As the result shows, the proportion of financial vocabulary whose meaning could be acquired by matching with GE is 533 out of 947 (with total meanings of two to thirty six), accounting for $56.3 \%$. and from three to thirtysix is 401 out of 541 , accounting for $74.1 \%$. This analysis suggests that it is economical for FE learners to establish the relation between FE terms and GE vocabulary.
3.2 A wide variation of etymologyvisualization techniques

Based on the analysis above, we identified and applied helpful teaching techniquees to FE vocabulary. Teachers can combine more than one techniques (Pinter, 2006). A word can be defined in various ways, but three significant aspects teachers need to be aware of and focus 
on are form, meaning, and use (Ibrahim, 2015). Linking etymology-visualization techniques together with the meaning of vocabulary, we produce 'derivative reasoning technique' and 'monolingual reasoning technique' while together with the form of vocabulary we produce 'multilingual reasoning technique', 'word decomposition technique' and 'definition grouping technique'. Following are descriptions of how these techniques are applied in our case, together with explanations or justifications for their use.

\subsubsection{Derivative reasoning technique}

Concerning teaching the underlying meaning of a word, Schmitt (2008) says, 'Many words are polysemous in English; that is, they have more than one meaning. By defining the underlying meaning, we maximize the effect of the teaching because we enable students to understand the word in a much wider variety of contexts.' Paul (1994) also states that 'Teaching vocabulary effectively begins with building on what students already know. By opening a concept in the students' minds and having them call up familiar words related to the concept, you are preparing them to add new words to their lexical networks. It is important to ensure that learners master the high-frequency words of the L2 before moving on to the less frequent words. Therefore, the level of the vocabulary, as well as the methods of teaching it, should suit the learners.' 'Semantic motivation is a kind of psychological association, and it can explain the word's original meaning and other meaning-related items. As to many words in a language, their metaphorical referents have a certain similarity with their original meaning referents in their shape, function, characteristic, etc.' (Shigao, 2012).

Familiar English vocabulary is of high frequency in everyday life. FE vocabulary and familiar English vocabulary are similar in nature. To expand the extent of the familiar English vocabulary into the new FE vocabulary is helpful. To reason FE vocabulary is to relate to its original meaning which learners are already familiar with.

Teaching the target FE vocabulary is accompanied by directly or indirectly relating to its original meaning and visualizing it. Longman dictionary states that 'portfolio' has its Italian origin, portfolio, from portare 'to carry' + foglio 'leaf, sheet'. So the original meaning of 'portfolio' is a large flat case with many sheets for carrying pictures, documents, etc. Teachers show a visual aid of a large flat case with many sheets (original portfolio) to the learners and let them directly relate each 'sheet' with each 'stock' or 'bond' or other financial instruments. Then learners can accept the financial meaning of 'portfolio' as 'diversification of investment'.

A financial vocabulary 'spread' is 'the difference between the interest rate that a bank pays for borrowing money and the rate at which it is prepared to lend it'. The original meaning of 'spread' is 'open' or 'extend'. Longman dictionary says that 'if something spreads or is spread, it becomes larger or moves so that it affects more people or a larger area.' How to relate 'becoming larger' with 'difference'? Teachers show a video of a pigeon spreading its wings and let students try to find something helpful for them to extract the meaning of the financial vocabulary 'spread'. One student says, 'a pigeon spreads its wings, 'spread' in this video is the same as 'spread' in financial terminology in their appearance.' Then teachers let students try to find where 'spread' means 'difference' showing another visual aid like the following. 


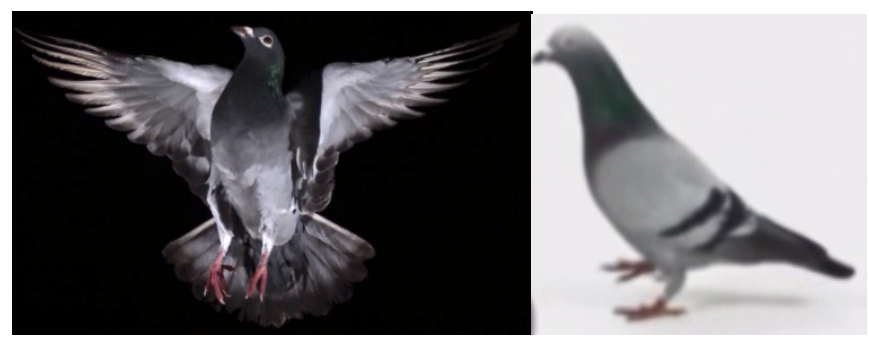

Figure 2. A pigeon spreading its wings (1)

Then another student says, 'Folded wings and spread wings are different in the area.' Teachers metaphorize the borrowing interest rate into folded wings and lending interest rate into spread wings. And the difference is understood as 'spread'.

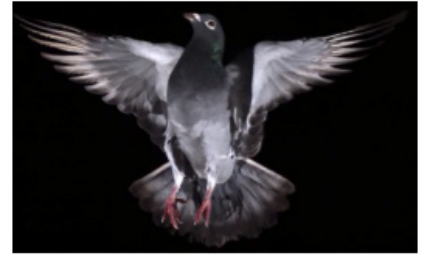

(lending rate)

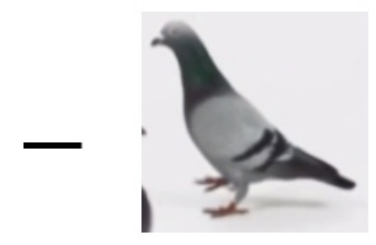

(borrowing rate)

Figure 3. A pigeon spreading its wings (2)

Furthermore, they can generalize that 'spread' is 'the difference between the prices at which something is bought and sold or the interest rates for lending and borrowing money.'

Here, if they were not shown a visual aid of spreading feathers, it would be hard to motivate their brain to link a bird's spread to the financial meaning of spread.

Lakoff and Johnson (1980) state, 'The recent developments in cognitive linguistics have revealed how abstract meaning in language is shaped by bodily experience. Concepts, concrete or abstract, cannot be arbitrary, but instead, are constructed in a metaphorical way. They are based on human bodily experiences. Concepts are formed through body and mind's embodiment of the world and are understood through body and mind.'

It is also known that bodily experience can be memorized well. Combining bodily experience with the new FE vocabulary through visualization would enhance learners' understanding.
As for a financial vocabulary 'net profit', the original meaning of 'net' is 'something used for catching fish, insects or animals which is made of threads or wires woven across each other with regular spaces between them'. By using a net, fish remain in it without water. Teachers ask students to imagine netting their fish (profit) from the river (revenue).

A profit and loss account is one of the financial statements and has three elements: revenue, expense and net profit. It has a formula: 'Revenue - Expense $=$ Net profit'

Teachers metaphorize this formula as 'netting fish in the river'.

As for another vocabulary 'to write off', OBEDLE (2005) says as follows: (1) (in Accounting) to reduce the value of an asset in a company's accounts over a period of time: (2) (in Accounting) to remove a debt from a company's accounts because the money cannot be collected; to remove an asset that has no value. 
Teachers show a video aid of writing ' 1000 ' and erasing it one by one zero ' 0 ' to be 'blank'. Students watch the process of reducing from 1000 to 100 , from 100 to 10 , from 10 to 1 , from 1 to 0 by using an eraser and can understand what 'to write off' means.

\subsubsection{Monolingual reasoning technique}

People can name an object in a variety of ways for different reasons or due to various perspectives. Similarly, the same financial issue, concept or phenomenon can be referred to with different vocabulary items. For those items, teachers may try to explain to students such different reasons or perspectives, which can be helpful. Take 'standing order' and 'direct debit' as an example.

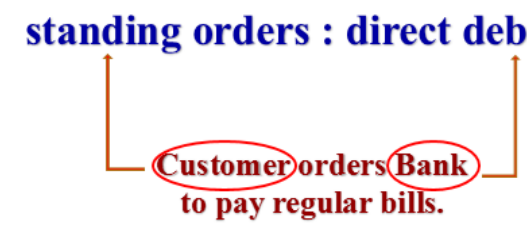

Figure 4. 'Standing order' \& 'direct debit'.

Teachers analyze the definition of 'standing order' and 'direct debit' in OBEDLE (2005).

'Standing order': an instruction that you give to a bank to pay somebody a fixed amount of money from your account on the same day each week, month, etc.

'Direct debit': an instruction to your bank to allow somebody else to take an amount of money from your account on a particular date, especially to pay bills.

The definitions say that a customer orders a bank to pay regular bills. When you focus on 'customer', then it is named 'standing order' (here 'standing' stands for 'continuing' or 'regular').

When you focus on 'bank', then it is named 'direct debit' (the bank receives an order from a customer and directly debit his or her account.)

Take 'debtors' and 'accounts receivable' as another example. Teachers change the definition of 'debtors' or 'accounts receivable' into another statement which is more

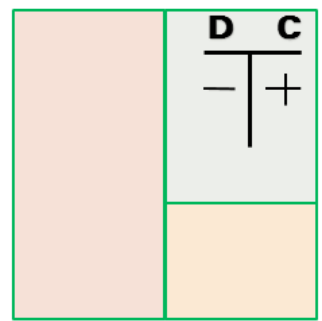

convenient for teaching.

Dictionaries may define the word as 'the amount of money that is owed to a company, which are recorded as assets on its balance sheet'.

Teacher may say: 'The amount of money that debtors owe to a company.' (1)

'The amount of money that a company can receive from debtors.' (2)

'Debtors' or 'accounts receivable' is composed of two elements: a debtor who should pay debt and the amount of money a creditor should receive. When you focus on the 'who', then it is named 'debtors' (British English). When you focus on the 'what', then it is named 'accounts receivable' (American English).

\subsubsection{Multilingual reasoning technique}

'There is no doubt that the first language (L1) exerts considerable influences on learning and using L2 vocabulary in a number of ways. Although using the L1 in second language learning is unfashionable in many quarters, 
given the ubiquitous nature of L1 influence, it seems perfectly sensible to exploit it when it is to our advantage.' (Schmitt, 2008). Comparing rather than matching up the meanings of L1 and L 2 vocabulary would enhance vocabulary learning also after the beginning stages of learning vocabulary.

Drawing a graph can help learners relate different ways of expressing depreciation methods shown below.

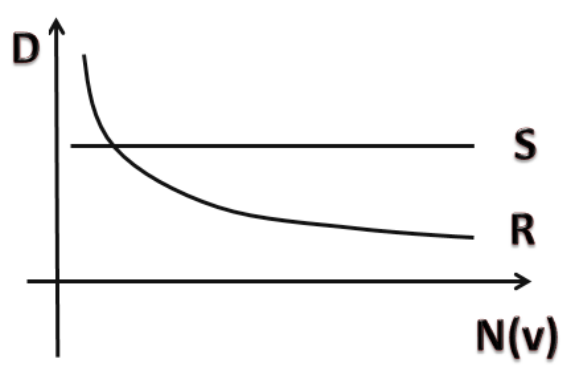

Figure 5. Depreciating methods.

(D: depreciated amount, S: straight line method, R: declining or reducing balance method, N: years) Table 2. English - Korean reasoning for some depreciation methods

\begin{tabular}{|c|c|c|c|}
\hline Language & Financial Vocabulary & Decomposed Elements & Composed Meaning \\
\hline English & $\begin{array}{l}\text { straight-line method } \\
\text { declining balance } \\
\text { method }\end{array}$ & $\begin{array}{l}\text { straight-line } \\
\text { method } \\
\text { declining balance } \\
\text { method }\end{array}$ & $\begin{array}{l}\text { method that draws a straight } \\
\text { line } \\
\text { method that draws a declining } \\
\text { line }\end{array}$ \\
\hline Korean & 정률법 & $\begin{array}{l}\text { fixed (정) } \\
\text { amount (액) } \\
\text { method (법) } \\
\text { fixed (정) } \\
\text { rate (률) } \\
\text { method (법) }\end{array}$ & $\begin{array}{l}\text { method that depreciates a fixed } \\
\text { amount every year }\end{array}$ \\
\hline $\begin{array}{r}\text { 3.2.4. Se } \\
\text { Teachers } \\
\text { financial vo } \\
\text { technical vo } \\
\text { already fam } \\
\text { may introdu } \\
\text { Microsoft } 0\end{array}$ & $\begin{array}{l}\text { nantic contrast technic } \\
\text { technique to teach } \\
\text { abulary by relating it } \\
\text { abulary which learner } \\
\text { liar with. For instanc } \\
\text { ce the technical tern } \\
\text { ffice to explain a nev }\end{array}$ & $\begin{array}{l}\text { tables in M } \\
\text { button of th } \\
\text { prompts ou } \\
\text { then indivi } \\
\text { big cell. T } \\
\text { combined' } \\
\text { bigger one } \\
\text { through vis }\end{array}$ & $\begin{array}{l}\text { crosoft office, we click the right } \\
\text { mouse, then the following screen } \\
\text { and we click "merge cells" and } \\
\text { ual cells are combined into a } \\
\text { achers metaphorize 'each cell } \\
\text { 'a company' and 'the combined } \\
\text { as 'a merged big company' } \\
\text { alizing table making. }\end{array}$ \\
\hline
\end{tabular}

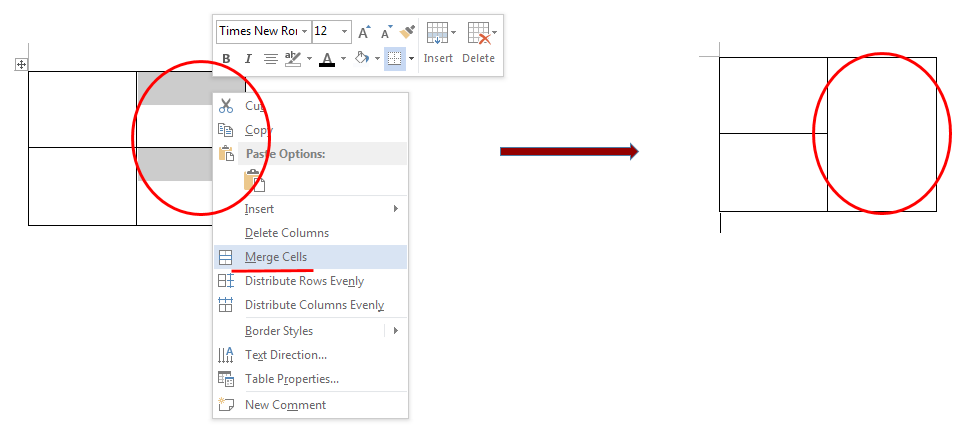

Figure 6. 'Merge Cells' = 'Merge Companies'. 
In teaching 'commercial bank', let learners understand what 'commerce' means and then what 'commercial bank' means. Commerce means trade or exchange $A$ for B. To lend money is to exchange money (A) for interest (B) and to receive money is to exchange interest (B) for money (A), which are the main businesses (loan and deposit) in commercial banks.

\subsubsection{Word decomposition technique}

We solve a tough math problem using known formulas. A new complex, long, strange vocabulary can be divided into pieces much simpler and more familiar to learners so that it can be more easily acquired. Nina Kisin (2014) reports that 'In Yugoslavia they use some effective ways to teach new FE lexemes, one of which is to play hangman and see if students could guess the missing letters, then to provide them with the definition in English dictionary (e.g. 'cash cow' as 'a very profitable business or part of a business') - quite a successful technique, as well as the translation of it into their mother tongue (Serbian). Students readily offer their translations of cash cow into Serbian, although they improvise some extent: kravamuzara, zlatnakoka... The teacher provides them with example sentences (input) to know how to use 'cash cow' in a sentence.'

As for the same lexeme 'cash cow', we use a different technique. Make a new word from an old one. That is to convert strange vocabulary ('cash cow') into familiar one ('cash' and 'cow'). After the Basic English course, students have already learnt that cow is a large female animal producing milk. Teachers let students replace 'milk' with 'cash'. Then 'milk-producing-cow' is converted into 'cashproducing-cow'. Students can automatically guess the meaning of cow as business or part of business with high yield.

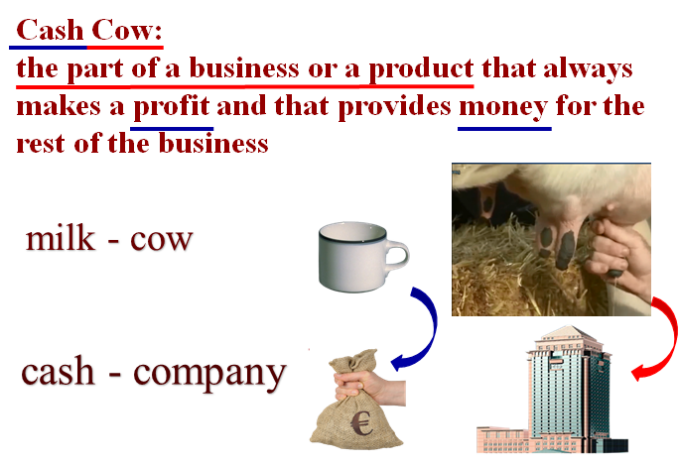

Figure 7. 'Milk-producing-cow' and 'cashproducing-company'.

'Solvency' can be decomposed into 'ability to solve' i.e. to make solid into liquid while 'liquidity' into 'ability to be liquid'. Teachers show students the visual aid of conversion of solid (ice) into liquid (water) then let them try to find where the difference between 'solvency' and 'liquidity' lies. They answer that 'solvency' shows the stage of solving i.e. melting ice into water (process) while 'liquidity shows being melted into water (result). Metaphorizing 'fixed asset' as 'solid' and 'current asset (like cash)' as 'liquid', learners can regard 'solvency' as 'ability to convert fixed asset into cash in such a case of liquidation' i.e. ability to pay long - term creditors. And also they can regard 'liquidity' as 'ability of being liquid' i.e. ability to having cash for short - term payment.

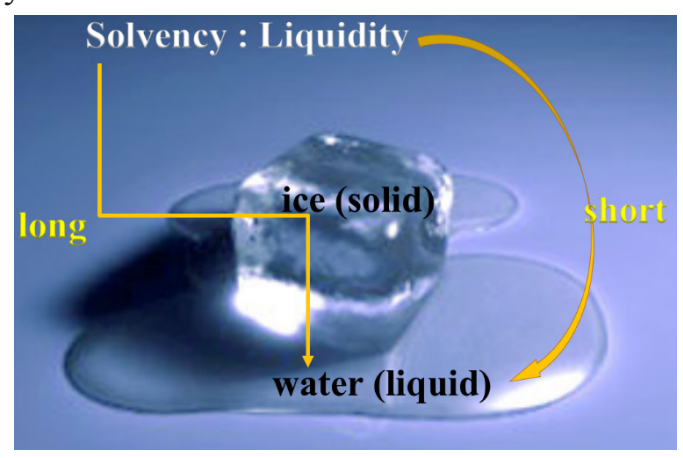

Figure 8. Solvency - liquidity. 
Similarly, 'irrecoverable'can be decomposed into pieces, i.e. ir (not) +re (again) + cover (pay) + able (can). So it can be understood as 'cannot pay back again'. Another vocabulary 'income' can be artificially decomposed into 'in' and 'come' and then means 'everything come into my pocket'. The other word 'underwrite' can be into 'under' and 'write'. 'To write under part of the paper is to sign in a contract'. Then learners can understand its usage in different cases. For example, as for an insurance company, to underwrite is to sign an insurance policy, i.e. to be responsible for an ensured risk. And as for an investment bank, to underwrite is to issue stocks for companies.

\subsubsection{Definition grouping technique}

This technique is to match up FE vocabulary in the word box with the corresponding explanation in groups by finding correlations (common or different points) between them. Shigao (2012) states that 'Some psychologists hold that things in good order and meaningful groupshave got greaterchancesto bememorized.' Teachers put a set of correlated vocabularies in groups along with corresponding explanations. Learners try to find out any relations in word box with explanation groups by combining known and unknown vocabularies. In the past, teachers put a task to match a vocabulary in a box with an individual explanation. Given no relations in this word box, learners could match only after consulting a bilingual dictionary. To group explanations corresponding to grouped vocabularies is to make it easy for learners to guess the new meaning of unknown words from known words. They may less depend on dictionaries and understand better through contexts. 'When meeting a new word, they can think about what they have already known about it, i.e. their previous knowledge and image schema, and link the new word with what they have already known to guess its meaning in the context.' (Shigao, 2012)
Appendix 2 illustrates the example of matching up words with explanations. In the traditional way, the task given is to match the words in the box with the definitions at random. In the new technique, teachers set the task with definitions grouped together. Then learners are asked to group words which look similar. The words are collected into groups according to their affixes such as 'econo -' words, 'quo -'words, '- ism' words. Learners then can complete matching tasks more easily.

\subsection{Efficiency analysis of etymology-visualization technique}

A sequence of associated learning through such an etymology-visualization technique can help students store the words in their long-term memory for later use; in that way, their lexicon gradually builds up. These are related to the three stages of cognition, namely acquisition, retention and retrieval. So in our experiment, we also examined how long and accurately learners can remember and use the target vocabulary provided through the use of the afore-described techniques.

We divided 114 participants at the average age of 21 into two groups: group A being the control group with 57 participants, and group B being the experimental group, also with 57 participants. The English proficiency levels between the two groups were found to be similar at the beginning of the study based on their latest exam results.

Table 3. Composition of participants based on their English proficiency

\begin{tabular}{lcc}
\hline $\begin{array}{c}\text { Latest Exam } \\
\text { Result (marks) }\end{array}$ & $\begin{array}{c}\text { Number of } \\
\text { students in } \\
\text { group A }\end{array}$ & $\begin{array}{c}\text { Number of } \\
\text { students in } \\
\text { group B }\end{array}$ \\
\hline A (4.5 5) & 3 & 3 \\
B (4.0 4.4) & 47 & 47 \\
C (3.5 3.9) & 7 & 7 \\
\hline
\end{tabular}


Group A was taught the mentioned financial vocabularies in a traditional way, i.e. by explaining to them in English as in dictionaries and merely matching them with Korean equivalents, while group B was taught in the new way, i.e. through etymologyvisualization techniques. Then after 3 months, all the participants were examined to evaluate their ability of putting the vocabularies into practice by presenting the context involving some of the mentioned words and having them translated into Korean. 7 vocabulary items were checked and students of each group were asked to respond to each item in Korean within
2 seconds to assess their retention. Individual sentences including the 7 vocabulary items were presented to the students a year after the course and students were asked to translate the target 7 items into Korean within a total of 53 seconds. They were not to translate the whole sentence into Korean as the experiment aimed at the evaluation of vocabulary cognition in practice. If they could not produce the Korean equivalents within the time allocated, they failed. Table 4 below presents the rate of success among the students concerning the retention of the 7 FE vocabulary items after a quarter and after a year.

Table 4 . How many participants succeeded in retaining new vocabulary items?

\begin{tabular}{ccccc}
\hline \multirow{2}{*}{ Target vocabulary } & \multicolumn{2}{c}{ after a quarter* } & \multicolumn{2}{c}{ after a year** } \\
\cline { 2 - 5 } & $\mathrm{A}(57)$ & $\mathrm{B}(57)$ & $\mathrm{A}(57)$ & $\mathrm{B}(57)$ \\
\hline cash cow & 46 & 49 & 23 & 42 \\
net profit & 37 & 43 & 21 & 38 \\
portfolio & 22 & 35 & 9 & 31 \\
spread & 19 & 37 & 11 & 39 \\
blue chip & 35 & 57 & 23 & 52 \\
straight line method & 37 & 56 & 29 & 56 \\
solvency & 42 & 47 & 39 & 41 \\
\hline AVERAGE & $34(59.6 \%)$ & $46(81.2 \%)$ & $22(38.8 \%)$ & $43(74.9 \%)$ \\
\hline
\end{tabular}

* within 14 seconds $(2 \times 7$ items $=14 \mathrm{~s})$

** within 53 seconds (Appendix 3)

Table 4 shows that the result of the experimental group (group B) $(81.2 \%$ $\$ 74.9 \%)$ is superior to that of the control

group (group A) $(59.6 \& 38.8 \%)$. We also measure the time needed for them to finish the task.

Table 5. How quickly do learners finish their task?

\begin{tabular}{ccccc}
\hline \multirow{2}{*}{ Time taken (minutes) } & \multicolumn{2}{c}{ Group A (57) } & \multicolumn{2}{c}{ Group B (57) } \\
\cline { 2 - 5 } & Participants & $(\%)$ & Participants & $(\%)$ \\
\hline $5-10$ & 2 & 3.5 & 3 & 5.3 \\
$11-15$ & 11 & 19.3 & 15 & 26.3 \\
$16-20$ & 12 & 21.1 & 17 & 29.8 \\
$24-25$ & 16 & 28.1 & 13 & 22.8 \\
$26-30$ & 13 & 22.8 & 7 & 12.3 \\
$31-35$ & 2 & 3.5 & 1 & 1.8 \\
$36-40$ & 1 & 1.8 & 1 & 1.8 \\
\hline Total average time & 23.3 & & 21.1 & \\
\hline
\end{tabular}


Table 5 shows that the experimental group did faster (21.1 minutes) than the control group (23.3 minutes).

Finally, we also examined how much these etymology-visualization techniques encourage the students by analyzing their attitude, i.e. how much it can turn the students' feeling of 'must do' into that of 'like to do'.

Table 6. How do students feel?

\begin{tabular}{ccccccccc}
\hline & \multicolumn{2}{c}{ Terrible } & \multicolumn{2}{c}{ Bored } & \multicolumn{2}{c}{ Interested } & \multicolumn{2}{c}{ Very interested } \\
& how many & $(\%)$ & how many & $(\%)$ & how many & $(\%)$ & how many & $(\%)$ \\
\hline A $(57)$ & 14 & 24.6 & 29 & 50.9 & 11 & 19.3 & 3 & 5.3 \\
B (57) & 5 & 8.8 & 7 & 12.3 & 30 & 52.6 & 15 & 26.3 \\
\hline
\end{tabular}

As for group A, $24.6 \%$ of the students feel terrible learning FE vocabulary in a traditional way, $50.9 \%$ feel bored, $19.3 \%$ feel interested and $5.3 \%$ feel very interested. Meanwhile in group B, 5\% of the students feel terrible learning FE vocabulary in the new way, $12.3 \%$ feel bored, $52.6 \%$ feel interested, and 26.3\% feel very interested. The figures demonstrate that the majority $(85.5 \%)$ of students in group A who were taught in a traditional way were not happy with their FE vocabulary learning while the majority (78.9\%) of group B students who were taught in the new way found much interest in it. This means these new techniquees encourage students to learn more as they not only need to do it but also they like to do it. Learning FE has been turned from a difficult and terrible task to an easy and interesting one.

\section{Conclusion}

ESP is intimately related to GE. We believe that ESP knowledge consists of the Major knowledge and English knowledge (ESP = Major knowledge + English knowledge). Financial English, one branch of ESP, consists of financial knowledge and English knowledge (Financial English $=$ Special knowledge + English knowledge). We also posit that is most important in teaching ESP (Financial English in this case) lies in vocabulary. FE learners should get a knowledge of vocabulary specific to their target major. It is necessary for them to notice the charactersistics peculiar to FE vocabulary. In FE teaching and learning, etymology and visualization combined can enhance acquisition, comprehension, and retrieval of FE vocabulary. As revealed in our experience, a variety of etymologyvisualization techniquees can be used: derivative reasoning technique, monolingual reasoning technique, multilingual reasoning technique, semantic contrast technique, word decomposition technique, and definition grouping technique. All of these are effective to different extents, which allows us to claim that etymology-visualization techniques are useful in ESP teaching/learning, especially FE vocabulary teaching/learning in our case.

To teach students how to learn is better than teaching them what is known. Through sharing this Korean experience, we believe that etymology-visualization techniques can provide learners with a leverage to fish more vocabulary needed to build up their ESP knowledge. Further research of this kind may find new techniquees for teaching/learning FE vocabulary in particular, and ESP vocabulary in general, by using graphics, relevant proverbs or idioms, to name just a few, which can offer more effective ways to help ESP learners elsewhere. 


\section{References}

Alan, D., \& Catherine, E. (Eds). (2004) the Handbook of Applied Linguistics, Blackwell Publishing.

Arnaud, P., \&Bejoint, H. (1992). Vocabulary and Applied Linguistic. Basingstoke: Macmillan.

Averil, C. (Ed). (2000). New Ways in Teaching Vocabularies. TESOL Press.

Bloor, M. \& Bloor, T. (1986) Languages for Specific Purposes: Practice and Theory. Centre for Language and Communication Studies Occasional Papers, 19. Dublin: Trinity College.

Cameron, L. (2001). Teaching languages to young learners. Cambridge: Cambridge University Press.

Carter, R., \& McCarthy, M. (Eds.). (1988). Vocabulary and language teaching. London: Longman.

Coady, J., \&Huckin, T. (Eds.). (1997). Second language vocabulary acquisition. Cambridge: Cambridge University Press.

Crystal, D. (2003). English as a Global Language (2nd ed.). Cambridge: Cambridge University Press.

Flowerdew, J. \& Peacock, M. (2001a) Issues in EAP: a preliminary perspective. In J. Flowerdew \& M. Peacock (eds.), Research perspectives on English for academic purposes (pp. 8-24). Cambridge:

Cambridge University Press.

Ibrahim, M. A. (2015). Vocabulary input in English language teaching: Assessing the vocabulary input in English language teaching: Assessing the vocabulary load in spine five. International Journal of English Language and Linguistics Research, 3, 1-14.

Karen, L. V., Vera, J.W., Karen, L., Linda, M. P., Stephen, P. N., \& John, M. (2011). ASEJ, 41(1), 22-27.

Lakoff, G., \& Johnson, M. (1980). Metaphor We Live
By. Chicago: The University of Chicago Press.

Masoud, H., \&Masoud A. (2011). Etymology: a word attack strategy for learning the English vocabulary. Procedia - Social and Behavioral Sciences, 28, 102106.

Mayer, R. E., \& Anderson, R. B. (1991). Animations Need Narrations: An Experimental Test of a Dual-Coding Hypothesis. Journal of Educational Psychology, 83, 484-490.

Mofareh, A. (2015). The importance of vocabulary in language learning and how to be taught. International Journal of Teaching and Education.3(3). 26-30.

Nation, I. S. P. (1990). Teaching and learning vocabulary. Boston, Mass: Heinle\&Heinle Publishers.

Nation, I. S. P. (2001). Learning vocabulary in another language. Cambridge: Cambridge University Press.

Nina, K. (2014). Teaching and Learning Financial English Vocabulary. ELTA Journal, 2(2), 103-113.

Paul, N. (1994). New ways in Teaching Vocabulary. TESOL

Pinter, A. (2006). Teaching young language learners. Oxford: Oxford University Press.

Schmitt, N. (2000). Vocabulary in language teaching. Cambridge University Press.

Schmitt, N. (2008). Teaching Vocabulary. Pearson Education published.

Schmitt, N., \& McCarthy M. J.(Eds.) (1997). Vocabulary: Description, Acquisition and Pedagogy. Cambridge: Cambridge University Press.

Shigao, Z. (2012). Studies and Suggestions on English Vocabulary Teaching and Learning. English Language Teaching, 5, 130-134

Wilkins, D.A. (1972) Linguistics in Language Teaching. Australia: Edward Arnold.

\section{Appendix 1}

Some British and American terms for identical financial phenomena

\begin{tabular}{cc}
\hline British English & American English \\
\hline debtors & accounts receivable \\
creditors & accounts payable \\
share & stock \\
stock & inventory \\
profit and loss account & income statement \\
share premium & paid - in surplus \\
quote & list \\
merchant bank & investment bank \\
investment trust & mutual fund \\
\hline
\end{tabular}




\section{Appendix 2}

An example of definition grouping assignment:

monetarism, protectionism, economic, economy, economize, economical, consumer, customer, balance of payments, balance of trade, quota, quorum, account receivable, account payable, agent, merchant, middleman, broker

Group A:

- The theory and policy that considers the best way to manage an economy and keep inflation low is by controlling the amount of money and credit that is available.

- The principle or practice of protecting a country's own industry by taxing foreign goods.

Group B:

- (Adjective) not wasting time or money.

- (Adjective) connected with the word economy and the subject of economics.

- (Noun) the relationship between production, trade and the supply of money in a particular country or region.

- (Verb) to use less money, time, etc. than you normally use.

Group C:

- The difference in value between imports and exports of goods over a particular period.

- The difference between the amounts of money one country pays to other countries and the amount it receives.

Group D:

- The smallest number of people who must be at a meeting before it can begin or decisions can be made.

- The limited amount of things that is officially allowed.

Group E:

- The amounts of money that are owed to a business by its customers (debtors), shown as an asset on its balance sheet.

- The amounts of money that a business owes to its suppliers or to people who have made loans (its creditors), shown as a liability on its balance sheet.

Group F:

- Money that employees receive for doing their job, especially professional employees or people working in an office, that is usually paid every month.

- Money that you earn, usually every week, for work or services.

Group G:

- A person or a company in a particular market, such as securities, commodities, insurance, etc.

- A general term for agents, brokers, dealers, merchants, traders, wholesalers, retailers, and other marketing intermediaries.

- A person who negotiates purchases and sales in return for commission or a fee.

- A person who stocks and resells components or goods to manufacturers or retailers. 
Group H:

- The end-user of goods or services, whose needs are satisfied by producers.

- A person (or company) who buys a product or service from a producer or a shop.

\section{Appendix 3}

Test: Translate the underlined words in the following sentences into Korean within the time allocated.

\begin{tabular}{|c|c|c|}
\hline No & Sentences & $\begin{array}{l}\text { Time allocated } \\
\text { (seconds) }\end{array}$ \\
\hline 1. & $\begin{array}{c}\text { Cash cow usually has well-established brand and generates a } \\
\text { continuing flow of cash. }\end{array}$ & 7 \\
\hline 2. & $\begin{array}{l}\text { In other words, a sale at a price higher than marginal unit cost will } \\
\text { increase the net profit of the manufacturer even though the sales price } \\
\text { does not cover average total unit cost. }\end{array}$ & 12 \\
\hline 3. & $\begin{array}{l}\text { It is our responsibility to carry out efficient portfolio management } \\
\text { from a risk and return perspective. }\end{array}$ & 7 \\
\hline 4. & $\begin{array}{c}\text { The spread between high- and low-grade bonds reflects investor } \\
\text { confidence about the economy. }\end{array}$ & 7 \\
\hline 5. & Blue chips have dependable dividends. & 5 \\
\hline 6. & $\begin{array}{l}\text { If a new machine purchased for } \$ 1200 \text { was estimated to have a useful } \\
\text { life of ten years and a salvage value of } \$ 200 \text {, annual depreciation } \\
\text { under the straight-line method would be } \$ 100 \text {, charged at } \$ 100 \text { a year. }\end{array}$ & 9 \\
\hline 7. & $\begin{array}{l}\text { The positive figures of cash flow statement show a high level of } \\
\text { solvency. }\end{array}$ & 6 \\
\hline
\end{tabular}




\title{
ƯNG DỤNG CÁC KỸ THUẬT TỪ NGUYÊN HỌC-TRỰC QUAN HÓA TRONG GIẢNG DẠY TỨ VỰNG TIẾNG ANH TÀI CHÍNH QUA KINH NGHIỆM TRIỀU TIÊN
}

\author{
Chung-Sim Ri, Chol-Su Kang \\ Đại học Kim Nhật Thành, Cộng hòa dân chủ nhân dân Triều Tiên
}

Tóm tắt: Người ta thường cho rằng sinh viên học tiếng Anh chuyên ngành (ESP) nói chung, và sinh viên học tiếng Anh Tài chính nói riêng nhận thấy tiếng Anh chuyên ngành khó hơn tiếng Anh phổ thông vì nhiều lí do, trong đó có sự khác biệt giữa tiếng Anh phổ thông và tiếng Anh chuyên ngành. Bài viết của chúng tôi trước hết xác định những yếu tố quan trọng nhất trong giảng dạy tiếng Anh Tài chính thông qua việc làm rõ những khác biệt đó giữa tiếng Anh phổ thông và tiếng Anh Tài chính, đồng thời chỉ rõ đặc thù của tiếng Anh Tài chính. Tiếp đó, chúng tôi chia sẻ kinh nghiệm tìm kiếm những kỹ thuật dạy từ vựng tiếng Anh Tài chính hiệu quả để giúp sinh viên Triều Tiên khắc phục những khó khăn gặp phải khi học môn Tiếng Anh Tài chính so với môn Tiếng Anh phổ thông. Chúng tôi đã thử nghiệm nhiều kỹ thuật khác nhau, kết hợp giữa từ nguyên học với các biện pháp trực quan hóa để dạy từ vựng tiếng Anh Tài chính như biện giải quá trình phái sinh từ vựng đơn ngữ và đa ngữ, biện pháp đối sánh ngữ nghĩa, phân tích thành tố cấu tạo từ, và phân loại các định nghĩa, khái niệm thể hiện qua thuật ngữ tiếng Anh Tài chính. Chúng tôi cũng đã thử kiểm tra mức độ lưu giữ từ vựng tiếng Anh Tài chính của 114 sinh viên chia đều thành hai nhóm: nhóm thử nghiệm (giáo viên thử áp dụng những biện pháp từ nguyên học kết hợp với trực quan hóa trong giảng dạy từ vựng) và nhóm đối chứng (giáo viên dạy theo cách thức truyền thống) tại hai thời điểm 3 tháng và 1 năm sau khi được học những từ đó, và kết quả ban đầu cho thấy những kỹ thuật từ nguyên học-trực quan hóa này đạt hiệu quả nhất định. Mục đích sâu xa nhất của bài viết này là phác họa tình hình dạy/học tiếng Anh chuyên ngành ở đất nước chúng tôi với hy vọng là những gì hiệu quả ở Triều Tiên cũng có thể được phát huy ở các nơi tương tự trên thế giới.

Từ khóa: từ nguyên học, trực quan hóa, từ vựng tiếng Anh chuyên ngành, tiếng Anh Tài chính 